\title{
TET2 wt Allele
}

National Cancer Institute

\section{Source}

National Cancer Institute. TET2 wt Allele. NCI Thesaurus. Code C95253.

Human TET 2 wild-type allele is located in the vicinity of $4 \mathrm{q} 24$ and is approximately $134 \mathrm{~kb}$ in length. This allele, which encodes methylcytosine dioxygenase TET 2 protein, plays a role in cytosine metabolism. Mutation of the gene is associated with myeloproliferative disorders, polycythemia vera, systemic mastocytosis and myelodysplastic syndromes. 